\title{
Free-Radical Reaction of Iron(II) Dichloroclathrochelate with 1,3-Dioxolane Radical Derivative: Synthesis and Structure of Macrobicyclic tris-Dioximate Bearing 1,3-Dioxolan-2-yl Ribbed Substituent
}

\author{
Mikhail A. Vershinin, ${ }^{a}$ Alexey B. Burdukov, ${ }^{a}{ }^{@}$ Natalie V. Pervukhina, ${ }^{a}{ }^{2}$ lia V. Eltsov, ${ }^{\mathrm{b}}$ \\ and Yan Z. Voloshin ${ }^{\mathrm{c}}$ \\ ${ }^{a}$ Nikolaev Institute of Inorganic Chemistry SB RAS, 630090 Novosibirsk, Russia \\ ${ }^{\mathrm{b}}$ Novosibirsk State University, 630090 Novosibirsk, Russia \\ 'Nesmeyanov Institute of Organoelement Compounds RAS, 110991 Moscow, Russia \\ ${ }^{\circledR}$ Corresponding authore-mail: lscc@niic.nsc.ru
}

Free-radical substitution of chlorine atom of the fluoroboron-capped iron(II) dichloroclathrochelate with 1,3-dioxolan2-yl radical proceeds with high regioselectivity, predominantly yielding the corresponding monofunctionalized cage complex. Its molecular structure has been determined both in solution and in solid state using multinuclear NMR spectroscopy and a single-crystal X-ray diffraction experiment, respectively.

Keywords: Clathrochelates, iron(II), reactions of coordinated ligands, homolytic reactions.

\section{Свободно-радикальная реакция дихлорзамещенного клатрохелата железа(II) с радикалом 1,3-диоксолана: синтез и структура макробициклического трис-Аиоксимата с реберным 1,3-Аиоксолановым заместителем}

\author{
М. А. Вершинин, ${ }^{a}$ А. Б. Бурдуков, ${ }^{a}$ Н. В. Первухина, ${ }^{a}$ И. В. Ельцов, ${ }^{\mathrm{b}}$ \\ Я. З. Волошин \\ ${ }^{a}$ Институт неорганической химии им. А.В. Николаева СО РАН, 630090 Новосибирск, Россия \\ ${ }^{\mathrm{b}}$ Новосибирский государственный университет, 630090 Новосибирск, Россия \\ 'Институт элементоорганических соединений им. А.Н. Несмеянова РАН, 110991 Москва, Россия \\ ${ }^{\circledR}$ E-mail:lscc@niic.nsc.ru
}

\begin{abstract}
Свободно-радикальное замещение атома хлора в дихлорзамещенном клатрохелате железа(II), сшитом группой B-F, радикалом 1,3-диоксолан-2-ила проходит с высокой региоселективностью и в основном приводит к продукту монозамещения. Его молекулярная структура была определена в растворе и твердой фазе методом спектроскопии ЯМР на различных ядрах и РСА.
\end{abstract}

Ключевые слова: Клатрохелаты, железо(II), реакции координированных лигандов, гомолитические реакции. 
Recently we have reported ${ }^{[1-4]}$ that the iron(II) dichloroclathrochelate $\mathrm{FeBd}_{2}\left(\mathrm{Cl}_{2} \mathrm{Gm}\right)(\mathrm{BF})_{2}$ (where $\mathrm{Bd}^{2-}$ and $\mathrm{Cl}_{2} \mathrm{Gm}^{2-}$ are $\alpha$-benzyldioxime and dichloroglyoxime dianions, respectively) smoothly undergoes the free-radical substitution with carbon-centered radical species - the derivatives of cyclohexane, alcohols and cyclic ethers (such as 1,4-dioxane and tetrahydrofuran) (Scheme 1,i). In this paper, we describe synthesis, spectra and X-ray structure of the macrobicyclic complex $\mathrm{FeBd}_{2}(\mathrm{Cl}(\mathrm{Diox}) \mathrm{Gm})(\mathrm{BF})_{2}$ (where Diox is 1,3-dioxolan-2-yl radicals) with one functionalizing ribbed substituent as a product of the similar substitution reaction with free-radical derivative of 1,3-dioxolane (Scheme 1,ii). ${ }^{[5]}$ atoms are located in almost one plane (the deviations from their mean plane do not exceed $0.06 \AA$ ), whereas the bridging carbon atom is deviated from this plane by $0.34 \AA$. It should be noted that, although the lack of chiral centers, the molecule $\mathrm{FeBd}_{2}(\mathrm{Cl}(\mathrm{Diox}) \mathrm{Gm})(\mathrm{BF})_{2}$, crystallizes in chiral space group $P 2,2,2$, like its chiral macrobicyclic analogs $\mathrm{FeBd}_{2}(\mathrm{ClGm}(\mathrm{THF}))(\mathrm{BF})_{2}$ and $\mathrm{FeBd}_{2}(\mathrm{ClGm}(\mathrm{Dx}))$ $(\mathrm{BF})_{2}$ (where THF and Dx are tetrahydrofuryl and 1,4dioxanyl substituents, respectively); all these crystals have the similar unit cell dimensions.

The macrobicyclic structure of the complex $\mathrm{FeBd}_{2}(\mathrm{Cl}(\mathrm{Diox}) \mathrm{Gm})(\mathrm{BF})_{2}$ was also confirmed by solution NMR spectra; assignment of the signals is represented

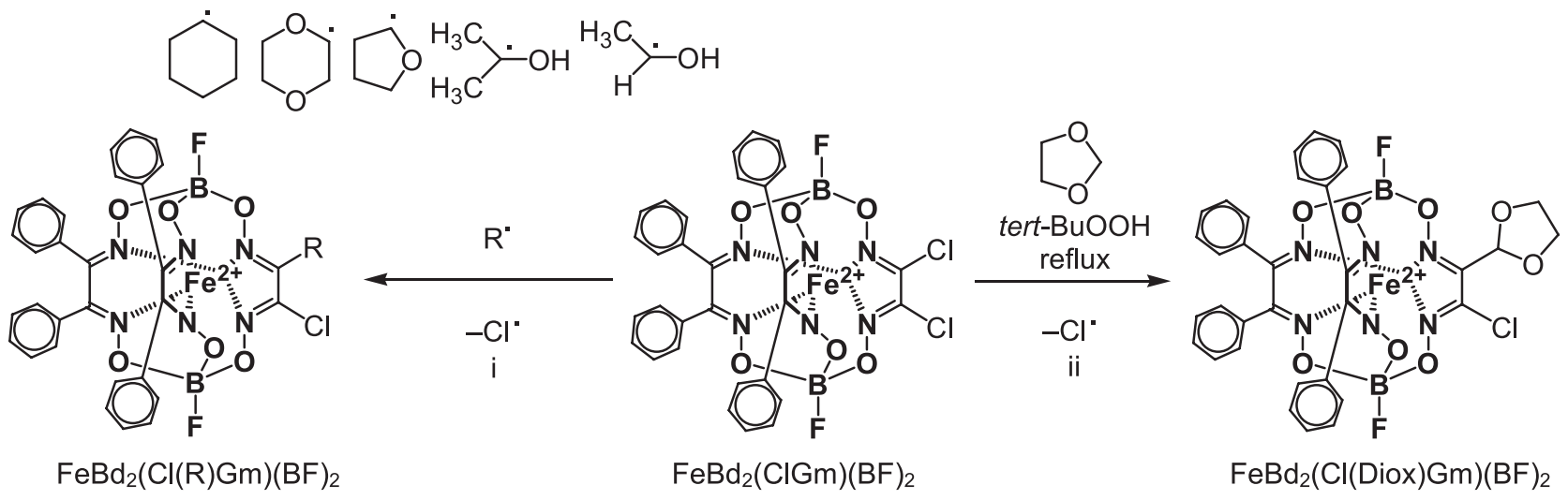

Scheme 1.

The reaction of the dichloroclathrochelate precursor $\mathrm{FeBd}_{2}\left(\mathrm{Cl}_{2} \mathrm{Gm}\right)(\mathrm{BF})_{2}$ with 1,3-dioxolane in boiling benzene in presence of tert-butylhydroperoxide as a radical initiator proceeds smoothly and affords the monofunctionalized macrobicyclic product $\mathrm{FeBd}_{2}(\mathrm{Cl}(\mathrm{Diox}) \mathrm{Gm})(\mathrm{BF})_{2}$ in a good yield (Scheme 1); such result is also characteristic for other earlier-studied reagents of this type. We also isolated a small amount of the disubstituted clathrochelate product $\mathrm{FeBd}_{2}\left((\mathrm{Diox})_{2} \mathrm{Gm}\right)(\mathrm{BF})_{2}$ and characterized it by ${ }^{1} \mathrm{H}$ NMR spectroscopy $\left\{\delta_{\mathrm{H}}^{1}=6.32\left(\mathrm{~s}, 2 \mathrm{H}, \mathrm{C}^{2} \mathrm{H}\right), 4.17\right.$ $\left.\left(\mathrm{m}, 8 \mathrm{H}, \mathrm{CH}_{2}\right), 7.38(\mathrm{~m}, 20 \mathrm{H}, \mathrm{Ph})\right\}$; however, we failed to evaluate a reproducible synthetic protocol for the iron(II) cage complex. The molecular structure of this monofunctionalized clathrochelate $\mathrm{FeBd}_{2}(\mathrm{Cl}(\mathrm{Diox}) \mathrm{Gm})$ $(\mathrm{BF})_{2}$ was confirmed by single-crystal X-ray diffraction study in solid state and by multinuclear NMR experiments in solution.

General view of the molecule $\mathrm{FeBd}_{2}(\mathrm{Cl}(\mathrm{Diox}) \mathrm{Gm})$ $(\mathrm{BF})_{2}$ is shown in Figure 1 (X-ray diffraction data). Its cage framework possesses a geometry that is intermediate between a trigonal-prism (TP) and trigonal antiprism (TAP) characteristic of the boron-capped tris-dioximate iron(II) clathrochelate: ${ }^{[10]}$ the average distortion angle $\varphi$ of the $\mathrm{FeN}_{6}$-coordination polyhedron is equal to $25.8^{\circ}\left(\varphi=0^{\circ}\right.$ for an ideal TP; $\varphi=60^{\circ}$ for a TAP), and the height $h$ of such TP-TAP polyhedron is approximately $2.31 \AA$; the Fe-N distances fall in the narrow range $(1.891(1)-1.919(1) \AA)$. The ribbed 1,3-dioxolan-2-yl substituent at this cage framework has an envelope conformation: its four carbon

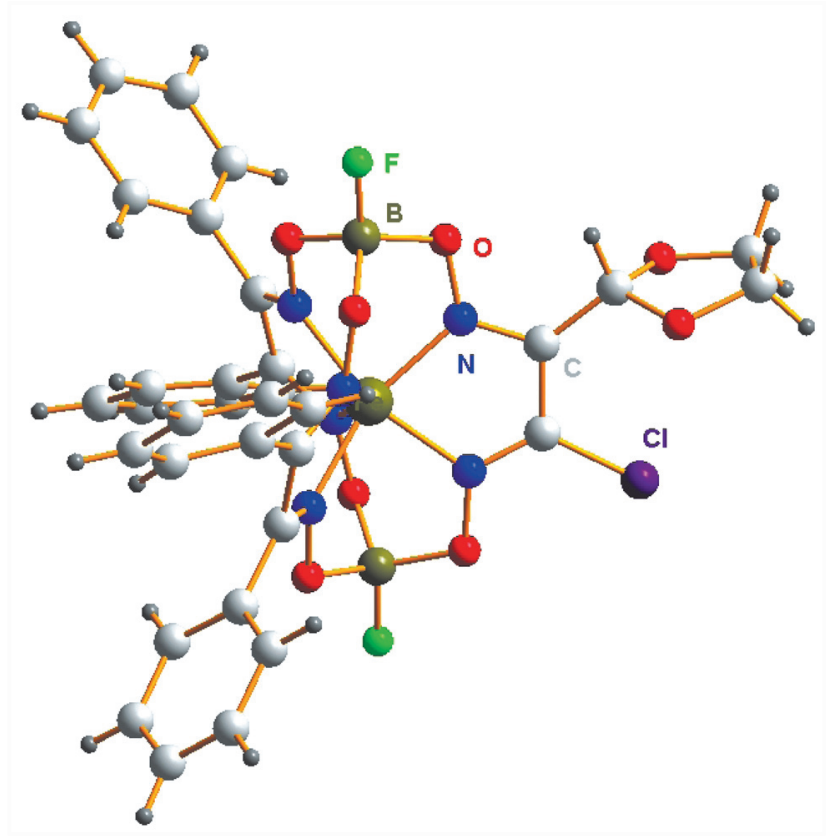

Figure 1. General view of the clathrochelate $\mathrm{FeBd}_{2}(\mathrm{Cl}(\mathrm{Diox}) \mathrm{Gm})(\mathrm{BF})_{2}$.

in Scheme 2. The proton spin system of the ribbed 1,3-dioxolanyl substituent at cage framework was additionally analyzed by computer simulation; Scheme 2 


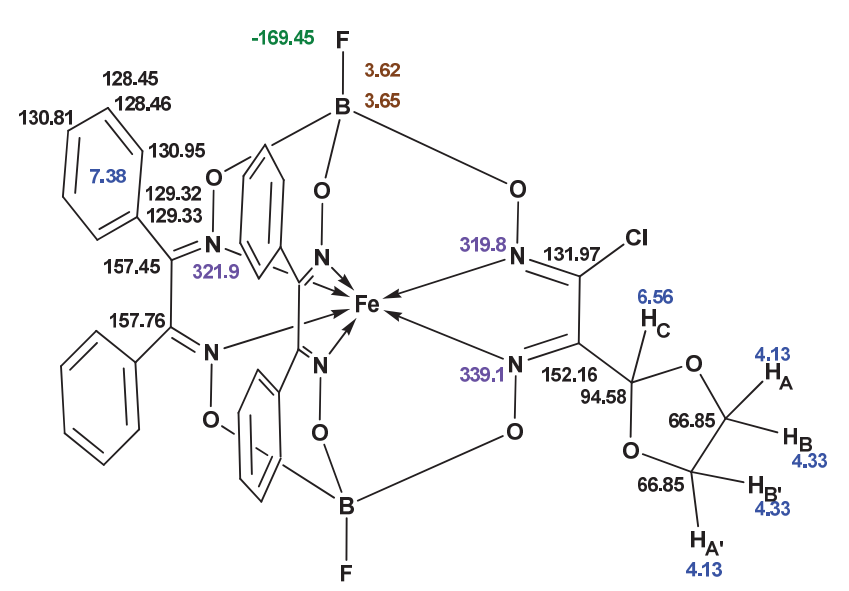

Scheme 2. Attribution of NMR signals for $\mathrm{FeBd}_{2}\left(\mathrm{Cl}(\right.$ Diox $\left.) \mathrm{GmCl}_{2}\right)(\mathrm{BF})_{2}$

illustrates its experimental ${ }^{1} \mathrm{H}$ NMR spectrum, while the corresponding chemical shifts and the ${ }^{1} \mathrm{H}-{ }^{1} \mathrm{H}$ coupling constants are summarized in Table 1.

Table 1. ${ }^{1} \mathrm{H}-{ }^{1} \mathrm{H} J$-coupling constants $(\mathrm{Hz})$ and chemical shifts (ppm) for the 1,3-dioxolanyl substituent

\begin{tabular}{cccccc}
\hline & \multicolumn{3}{c}{$J$} & \multirow{2}{*}{$\delta$} \\
\cline { 2 - 5 } & $\mathrm{H}_{\mathrm{A}^{\prime}}$ & $\mathrm{H}_{\mathrm{B}}$ & $\mathrm{H}_{\mathrm{B}^{\prime}}$ & $\mathrm{H}_{\mathrm{C}}$ & \\
\hline $\mathrm{H}_{\mathrm{A}}$ & 7.00 & -7.41 & 6.50 & 0.22 & \multirow{2}{*}{4.128} \\
$\mathrm{H}_{\mathrm{A}^{\prime}}$ & & 5.88 & -7.88 & -0.39 & \\
$\mathrm{H}_{\mathrm{B}}$ & & & 6.64 & 0.55 & \multirow{2}{*}{4.328} \\
$\mathrm{H}_{\mathrm{B}^{\prime}}$ & & & & -0.52 & \\
$\mathrm{H}_{\mathrm{C}}$ & & & & & 6.555 \\
\hline
\end{tabular}

Thus, the free-radical substitution of iron(II) dichloroclathrochelate with carbon-centered dioxanyl radical afforded the monofunctionalized macrobicyclic complex; this substitution occurs via the bridging carbon atom of functionalizing 1,3-dioxanyl substituents. This reaction proceeds with high regioselectivity; no other isomers of such cage complex were detected in the reaction mixture; this result can be explained by the stabilization of 1,3-dioxan-2yl radical species by two adjacent oxygen atoms. ${ }^{[1]}$

Acknowledgements. The authors thank Dr. N. Kuratieva (NIIC SB RAS) for collecting the single-crystal X-ray diffraction data.

\section{References and Notes}

1. Burdukov A.B., Vershinin M.A., Pervukhina N.V., Kozlova S.G., Eltsov I.V., Voloshin Y.Z. Russ. Chem. Bull. Int. Ed. 2011, 60, 2504-2509.

2. Vershinin M.A., Burdukov A.B., Pervukhina N.V., Eltsov I.V., Voloshin Y.Z. Inorg. Chem. Commun. 2013, 30, 159-162.

3. Vershinin M.A., Burdukov A.B., Eltsov I.V., Reznikov V.A., Boguslavsky E.G., Voloshin Y.Z. Polyhedron 2011, 30, 12331237.

4. Vershinin M.A., Burdukov A.B., Pervukhina N.V., Eltsov I.V., Voloshin Y.Z. Macroheterocycles 2012, 5, 11-16.
5. The dichloroclathrochelate precursor $\mathrm{FeBd}_{2}\left(\mathrm{Cl}_{2} \mathrm{Gm}\right)(\mathrm{BF})_{2}$ was prepared as described in ref. ${ }^{[6]}$. Benzene was washed with concentrated sulfuric acid and then distilled. 1,3-dioxolane was dried with $\mathrm{KOH}$ and distilled off. The commercially available tert-butylhydroperoxide solution in $n$-decane (SAF), silica gel 230-400 mesh (Alfa Aesar), other solvents and reagents (SAF) were used without purification. The ${ }^{1} \mathrm{H}$, ${ }^{11} \mathrm{~B},{ }^{19} \mathrm{~F}$ and ${ }^{13} \mathrm{C}\left\{{ }^{1} \mathrm{H}\right\}$ NMR spectra of the complex obtained were recorded in $\mathrm{CD}_{2} \mathrm{Cl}_{2}$ solution with a Bruker Avance III 500 spectrometer (working frequencies $500.13\left({ }^{1} \mathrm{H}\right), 160.46$ $\left({ }^{11} \mathrm{~B}\right), 470.59\left({ }^{19} \mathrm{~F}\right)$, and $\left.125.76 \mathrm{MHz}\left({ }^{13} \mathrm{C}\right)\right)$. The ${ }^{1} \mathrm{H}$ and ${ }^{13} \mathrm{C}$ NMR chemical shifts are given in the $\delta$ scale and referred to residual proton and carbon signals of this solvent $(5.34 \mathrm{ppm}$ for $\mathrm{CHDCl}, 53.8 \mathrm{ppm}$ for $\mathrm{CD}_{2} \mathrm{Cl}_{2}$ ), the signal assignment in the corresponding spectra and structure determination were carried out on the basis of 2D HMBC NMR spectra. The ${ }^{11} \mathrm{~B}$ and ${ }^{19} \mathrm{~F}$ NMR chemical shifts are referred to external standarts $\mathrm{BF}_{3} \cdot \mathrm{O}\left(\mathrm{C}_{2} \mathrm{H}_{5}\right)_{3}$ and TFT, respectively. ${ }^{15} \mathrm{~N}$ NMR spectrum was obtained as projection of $2 \mathrm{D}{ }^{1} \mathrm{H}-{ }^{15} \mathrm{~N}$-correlation. The ${ }^{15} \mathrm{~N}$-scale was calibrated with respect to the liquid ammonia $\left(\delta\left({ }^{15} \mathrm{~N}\right)=0 \mathrm{ppm}\right)$. The ${ }^{1} \mathrm{H}-{ }^{1} \mathrm{H} J$-couplings and the positions of signals of 1,3-dioxolane fragment were obtained and refined with spin-system modeling; NAMMRIT algorithm and the method of total-line-shape fitting were used $(\mathrm{RMS}=0.0396)$. All calculations were made using the Bruker Topspin v. 2.1 program package.

$\mathrm{FeBd}_{2}(\mathrm{Cl}($ Diox $) \mathrm{Gm})(\mathrm{BF})_{2}:$ 1,8-bis(2-fluorobora)-2,7,9,14,15,20hexaoxa-3,6,10,13,16,19-hexaaza-4,5,11,12-tetraphenyl-17chloro-18-(1,3-dioxolan-yl-2)bicyclo[6.6.6]eicosa-3,5,10,12, 16,18-hexaeno(2-) iron (2+). Complex $\mathrm{FeBd}_{2}\left(\mathrm{Cl}_{2} \mathrm{Gm}\right)(\mathrm{BF})_{2}$ $(0.11 \mathrm{~g}, 0.15 \mathrm{mmol})$ was dissolved in benzene $(20 \mathrm{ml})$ and 1,3-dioxolane $(2 \mathrm{ml})$ and $5.5 \mathrm{M}$ solution of tertbutylhydroperoxide in $n$-decane $(0.81 \mathrm{ml}, 4.6 \mathrm{mmol})$ were added. The reaction mixture was refluxed for $3 \mathrm{~h}$, cooled to r.t. and the additional portion of this radical initiator $(0.76 \mathrm{ml}$, $4.2 \mathrm{mmol}$ ) was added. The reaction mixture was refluxed for $5 \mathrm{~h}$, then rotary evaporated to dryness and the oily residue was dried in vacuo. The solid product was extracted with chloroform and the extract was chromatographically separated on silica gel $\left(1 \times 20 \mathrm{~cm}\right.$ column, eluent: $\left.\mathrm{CHCl}_{3}\right)$. The first elute, containing mainly the dichloroclathrochelate precursor, was thrown out and the second elute was collected, evaporated to dryness and dried in air. The solid product was recrystallized from dichloromethane:heptane 1:1 mixture and dried in vacuo. Yield: $0.071 \mathrm{~g}(60 \%)$. Anal. Calc. for $\mathrm{C}_{33} \mathrm{H}_{25} \mathrm{~N}_{6} \mathrm{O}_{8} \mathrm{ClB}_{2} \mathrm{~F}_{2} \mathrm{Fe}: \mathrm{C}, 50.5 ; \mathrm{H}, 3.6 ; \mathrm{N}, 10.2$. Found: $\mathrm{C}$, $50.5 ; \mathrm{H}, 3.2 ; \mathrm{N}, 10.7 \%$. ${ }^{1} \mathrm{H}$ NMR $\left(\mathrm{CD}_{2} \mathrm{Cl}_{2}\right): 4.13\left(\mathrm{~m}, 2 \mathrm{H}, \mathrm{CH}_{\mathrm{A}}\right.$ $\left.\mathrm{CH}_{\mathrm{A}}\right)$ and $4.33\left(\mathrm{~m}, 2 \mathrm{H}, \mathrm{CH}_{\mathrm{B}}, \mathrm{CH}_{\mathrm{B}}\right), 6.56\left(\mathrm{~s}, 1 \mathrm{H}, \mathrm{CH}_{\mathrm{C}}\right), 7.38$ (m, 20H, Ph). ${ }^{13} \mathrm{C}\left\{{ }^{1} \mathrm{H}\right\}$ NMR $\left(\mathrm{CD}_{2} \mathrm{Cl}_{2}\right): 66.85\left(\mathrm{~s}, \mathrm{CH}_{2}\right), 94.58$ (s, CH) $128.45,128.46$ (two s, 3-C (Ph)), 129.32, 129.33 (two s, 1-C (Ph)), $130.81(\mathrm{~s}, 4-\mathrm{C}(\mathrm{Ph})), 130.95(\mathrm{~s}, 2-\mathrm{C}(\mathrm{Ph})), 131.97$ (s, N=CCl), 152.16 (s, N=C-Diox), 157.45, 157.78 (two s, $\mathrm{PhC}=\mathrm{N}) .{ }^{11} \mathrm{~B}$ NMR $\left(\mathrm{BF}_{3} \cdot \mathrm{O}\left(\mathrm{C}_{2} \mathrm{H}_{5}\right)_{2}\right): 3.62\left(\mathrm{~d}, J_{{ }^{11} \mathrm{~B}^{-1}{ }^{19} \mathrm{~F}}=17.5\right.$ $\mathrm{Hz}), 3.65\left(\mathrm{~d}, \mathrm{~J}_{1^{11}{ }_{\mathrm{B}-}{ }^{19} \mathrm{~F}}=17 \mathrm{~Hz}\right) .{ }^{19} \mathrm{~F}$ NMR $\left(\mathrm{PhCF}_{3}\right):-169.29(\mathrm{~m}$, $\left.\mathrm{O}_{3} \mathrm{~B}^{\prime} \mathrm{F}+\mathrm{O}_{3} \mathrm{~B}^{\prime \prime} \mathrm{F}\right) .{ }^{15} \mathrm{~N}$ NMR $\left(\mathrm{NH}_{3}(\mathrm{liq})\right): 319.8(\mathrm{~N}=\mathrm{CCl}), 321.9$ $(\mathrm{N}=\mathrm{CPh}), 339.1(\mathrm{~N}=\mathrm{C}$-Diox $)$.

Single crystals of the complex $\mathrm{FeBd}_{2}(\mathrm{Cl}(\mathrm{Diox}) \mathrm{Gm})$ $(\mathrm{BF})_{2} \cdot 3 \mathrm{CH}_{2} \mathrm{Cl}_{2}$, suitable for the $\mathrm{X}$-ray diffraction experiment, were grown by slow evaporation of its saturated solution in dichloromethane:heptane 1:2 mixture at room temperature. The crystal system of $\mathrm{C}_{36} \mathrm{H}_{29} \mathrm{~B}_{2} \mathrm{Cl}_{7} \mathrm{~F}_{2} \mathrm{FeN}_{6} \mathrm{O}_{8} \quad(M=1037.27)$ is orthorhombic at $240 \mathrm{~K}: \quad a=15.557(3), \quad b=16.757(4)$, $c=16.879(4) \AA, V=4400.0(16) \AA^{3}$, space group $P 2{ }_{1} 2_{l}, Z=4$, $d_{\text {calc }}=1.566 \mathrm{~g} \cdot \mathrm{cm}^{-3}$. The intensities of 14603 reflections were measured with a Bruker Nonius X8Apex equipped with a $4 \mathrm{~K}$ $\mathrm{CCD}$ detector using graphite monochromated Mo-K $\alpha$ radiation $\left(\lambda=0.71073 \AA, 2 \theta<56.56^{\circ}\right) .8627$ independent reflections $(R($ int $)=0.0425)$ were used for the solution and refinement 
Free-Radical Reaction of the Iron(II) Dichloroclathrochelate with 1,3-Dioxolane Radical Derivative

of the structure. The semiempirical absorption correction was applied using intensities of equivalent reflections (SADABS).

${ }^{[7]}$ The structure was solved by the direct method ${ }^{[8]}$ and refined by full-matrix least squares against $F^{2}$. Non-hydrogen atoms were found on difference Fourier maps and refined with anisotropic displacement parameters (except those for one disordered solvate dichloromethane molecule). The positions of hydrogen atoms were calculated and included in the refinement in isotropic approximation by the riding model. C-Cl bond lengths for one of the solvate dichloromethane molecules were restrained during the refinement. The final convergence factors were $R_{l}(F)=0.0756$ and $w R_{2}=0.234$ for 4092 reflections with $I>2 \sigma(I)$ and 569 parameters. Goodness-of-fit $\left(F^{2}\right)=0.973$ for all reflections included in the last stage of refinement. All calculations were made using the SHELXTL-97 program package. ${ }^{[9]}$ CCDC reference number is 1036510.
6. Voloshin Y.Z., Zavodnik V.E., Varzatskii O.A., Belsky V.K., Palchik A.V., Strizhakova N.G., Vorontsov I.I., Antipin M.Y. Dalton Trans. 2002, 1193-1202.

7. Bruker AXS Inc., APEX2 (Version 1.08), SAINT (Version 7.03), and SADABS (Version 2.11). Bruker Advanced X-ray Solutions, Madison, Wisconsin, USA, 2004.

8. Burla M.C., Caliandro R., Camalli M., Carrozzini B., Cascarano G.L., De Caro L., Giacovazzo C., Polidori G., Spagna R. J. Appl. Cryst. 2005, 38, 381-388.

9. Sheldrick G.M. SHELXS97 and SHELX97. Programs for the Refinement of Crystal Structure, Release 97-2, University of Gottingen, Germany, 1998.

10. Voloshin Y.Z., Kostromina N.A., Krämer R. Clathrochelates: Synthesis, Structure and Properties. Amsterdam: Elsevier, 2002. $432 \mathrm{p}$

11. Zipse H. Top. Curr. Chem. 2006, 263, 163-189.

Received 27.11.2014

Accepted 10.12.2014 